\title{
An Observation on the Numerical and Topographical Relations of Taste Buds to Circumvallate Papillae of Japanese.*
}

\author{
By \\ Yoshiro Mochizuki. \\ From the Research Room of Anatomy, \\ Nihon University Dental College Kanda, Tokyo, Japan. \\ (Director; Prof. Dr. Y. Izawa.)

\section{Introduction}

The taste buds are the final end organs of taste, and found widely annong the animals. The development and evolution of taste buds in man had gone through various phases. Malpighi first discovered the lingual papillae in 1664, and there was a lapse of two hundred years before Loven (1867) and Schwalbe (1867) made a rediscovery of taste buds of mammals, independent of each other. The results of their investigations were published in 1868 and were fully treated and discussed. Lovén (1867), however, should be given credit as the first who described the taste buds of man.

The distribution of taste buds in fetus and infant is extended over wider area than in the adult. The fact is well known that the former have them in the mouth and also in the pharynx, whereas, in the adult they are generally found in the region of the circumvallate papillae, and mostly on the columnar papilla and on the wall of the trench. V. Wyss (1870) was the first investigator who published the number of taste buds on a circumvallate papilla and gave an average number of about 400 . But

* The author wishes to extend his grateful thanks to Prof. Y. Izawa, who suggested the problem and gave advice and criticism. He is also grateful to Dr. K. Satow, the Dean of Dental College who gave the time and facilities to carry out this experiment, and also to Prof. R. Hayashi, for their cordial assistance and supply of materials. 
we know nothing of his method nor as to how he reached this estimate. Krause (1876) described that there were approximately 2500 taste buds on a papilla and on its wall. He, likewise, did not give the method of his counting. Graberg (1899) gave an account and showed that the highest number fcr an adult papilla is between 100-150. He, however, stated further that there was much irregularities in the number of taste buds on each papilla, and said the lowest number found was between $40-50$. $\mathrm{He}$, too, did not mention his method.

The results of these three investigators are of little value from the scientific standpoint since nothing is known as to the method they used, though their historical value is of no small matter.

Heiderich (1906) made a significant contribution in this line of investigation by following a carefully planned method. He obtained 96 papillae from 43 individuals between birth to 20 years old. The materials were cut into serial sections of $10 \mu$ in thickness. The number of taste buds thus obtained from these sections were divided by the average numbers of sections per bud as determined for each papilla. The final estimate he came to under this method was an average of 248 buds on a papilla and 30 on the trench wall.

Arey, Tremaine and Monzingo (1936) examined 152 papillae which were taken from 51 individuals between the ages of 20-85 years old. The serial sections were cut at $20 \mu$. They determined the average number of sections per bud for each papilla 3 , and divided the total number of taste buds on each section of papilla by three. What Heiderich found among infants and youths, and the results obtained by Arey and his associates seemed to have completed the comparative studies of the number of taste buds on the papilla of the white race.

Their reports could be summed up as follows: The average number of taste buds on papilla between the ages of $20-70$ is 206 . Those of the wall of its trench are 49 . The average number decreased to 88 on a papilla between 75-85 years old, and there are only 13 taste buds on the wall of trench in this period.

Thus the number of taste buds of Europeans are looked into by these investigators but none so far has taken the initiative to determine the number of taste buds of Japanese. It is the author's hope that he may contribute something in the comparative studies of human anatomy by furnishing the facts obtained from Japanese in addition to that already found in the white race. 


\section{Materials}

128 fresh tongues were obtained from the Dept. of Pathology. They were hardened either in formalin or in Zenker's fixing solution. One to three well developed typical papillae were selected from each tongue. The total number of papillae was 253. The age ranged in this selection was from birth to 90 years old.

\section{Methods}

In order to prevent the contraction of the tissues of the material, they were treated with cedar wood oil to extract alcohol. The paraffin block was sectioned in parallel to the longitudinal axis of papilla in $10 \mu$ thickness. The sections were stained with haematoxyline and eosin.

The examination of these prepared slides show that the longitudinal axis of spindle shaped taste buds appear in parallel to the horizontal plane in the cross section of the series. Since the diameter of the papilla is from 20-60 $\mu$, it takes from 3 to 7 slides to complete a papilla. A divisor was determined by taking average number of sections per bud. In order to get this divisor accurately, a microscopic projection apparatus was used and the sections were enlarged 80 times on a tracing paper. The enlarged outlines of taste buds on the tracing papers were piled one upon another to see how many sheets will require to complete a picture. For example, 341 taste buds on one circumvallate papilla were projected by above mentioned apparatus on tracing papers. According to irregularity of the diameter of each bud, we obtained the following ratio.

116 taste buds were cut into 3 sections or a total of 348 section.

104 taste buds were cut into 4 sections or a total of 416 section.

64 taste buds were cut into 5 sections or a total of 320 section.

50 taste buds were cut into 6 sections or a total of 300 section.

7 taste buds were cut into 7 sections or a total of 49 section.

Thus 341 taste buds were cut into 1,433 sections, consequently each bud was cut into an average of 4.2 sections.

From birth to 90 years was divided with a unit of 10 year period, and the divisor determined by the microprojection method. The actual number of taste buds was counted in this manner for each period. The average number of taste buds on the circumvallate papilla which was cut into sections is not the same. Wach papilla may have different number of taste buds from the others.

The maximum number was found to be in 6.7 sections and the 
minimum was 2.0 sections. The average was low in the youngest age group, while the middle age group had the highest average, and it gradually becane lower again in old age. This shows that in youngest age group the papillae are not fully developed and in the old age group they undergo atrophy.

\section{Observation and Discussion}

The total number of the tongue obtained was 128 , and the total of 253 papillae were examined from these tongues. The ratio of the tongues and papillae is about $1: 2$. The total number of taste buds used was 50,119. The table 1 shows the number of tongues, papillae and taste buds according to the different age periods.

Table 1. Classification of material and the taste buds according to age, from birth to 90 years old.

\begin{tabular}{c|c|c|c}
\hline Age of individuals & $\begin{array}{c}\text { Number of } \\
\text { tongues studied }\end{array}$ & $\begin{array}{c}\text { Number of } \\
\text { papillae studied }\end{array}$ & $\begin{array}{c}\text { Number of } \\
\text { taste buds counted }\end{array}$ \\
\hline birth-10 jears & 23 & 50 & 13,385 \\
11 years-20 years & 12 & 30 & 8,198 \\
21 years-30 years & 11 & 20 & 4,786 \\
31 years-40 years & 11 & 22 & 5,348 \\
41 years-50 years & 13 & 20 & 2,552 \\
51 years-60 years & 6 & 7 & 1,362 \\
61 years-70 years & 20 & 40 & 5,852 \\
71 years-80 jears & 20 & 40 & 5,694 \\
81 years-90 jears & 12 & 24 & 2,942 \\
\hline total & 128 & 253 & 50,119
\end{tabular}

The number of taste buds on a papilla differs according to each papilla. The greatest number found on a papilla was 559 and the wall of its trench had 65 making a total of 624 . The lowest number found was 12 on a papilla and none on the wall of its trench.

Sometimes, we observed, that the number of taste buds on the walls of its trench was about the same as those on the papilla, but generally the papilla had a far greater number than on the wall of its trench. The number of taste buds on the wall of the trench is also not constant. The highest number was 173 and the lowest runs from 7 to zero.

Some papilla in a circumvallate papillae may have a great number of taste buds while the wall of its trench may not have any at all. Consequently, 
the number of taste buds on the wall of the trench does not proportionately correspond to the number on the papilla. Since the number of taste buds on a papilla is not constant, it is not possible to determine the number according to the age of the individual. We, however, tried to arrange as far as possible to figure out the average in the infant period, maturity period, and old age period.

Table 2 shows a comparison of the number of taste buds between Japanese and Europeans.

Table 2. The comparison of the number of taste buds of Japanese and Europeans. Japanese from birth to 90 years. Europeans from birth to 85 years. 128 Japanese tongues, 253 papillae. 94 European tongues and 248 papillae.

\begin{tabular}{|c|c|c|c|c|c|c|c|}
\hline Material & $\begin{array}{l}\text { Investi- } \\
\text { gator }\end{array}$ & $\begin{array}{c}\text { Age of } \\
\text { individuals }\end{array}$ & $\begin{array}{l}\text { Number } \\
\text { of indivi- } \\
\text { duals } \\
\text { studied }\end{array}$ & $\begin{array}{l}\text { Number } \\
\text { of } \\
\text { papillae. } \\
\text { studied }\end{array}$ & $\begin{array}{l}\text { Mean } \\
\text { number } \\
\text { of taste } \\
\text { buds on } \\
\text { each } \\
\text { papilla }\end{array}$ & $\begin{array}{l}\text { Nean } \\
\text { number } \\
\text { of taste } \\
\text { buds on } \\
\text { each wall }\end{array}$ & $\begin{array}{c}\text { Total } \\
\text { mean } \\
\text { number } \\
\text { of taste } \\
\text { buds }\end{array}$ \\
\hline \multirow{3}{*}{ Japanese } & \multirow{3}{*}{ Nochizuki } & $\begin{array}{l}\text { birth- } \\
20 \text { years }\end{array}$ & 35 & 80 & 242 & 48 & 269 \\
\hline & & $\begin{array}{l}21 \text { years- } \\
60 \text { years }\end{array}$ & 41 & 69 & 196 & 52 & 234 \\
\hline & & $\begin{array}{l}61 \text { years- } \\
90 \text { years }\end{array}$ & & 104 & 116 & 28 & 140 \\
\hline \multirow{3}{*}{ European } & Heiderich & $\begin{array}{l}\text { birth- } \\
\quad 20 \text { years }\end{array}$ & 43 & 96 & 248 & 30 & 270 \\
\hline & Arey & $\begin{array}{l}20 \text { years- } \\
70 \text { years }\end{array}$ & 38 & 106 & 206 & 49 & 254 \\
\hline & $\begin{array}{c}\text { and his } \\
\text { associates }\end{array}$ & $\begin{array}{l}74 \text { years- } \\
85 \text { years }\end{array}$ & 13 & 46 & 88 & 13 & 111 \\
\hline
\end{tabular}

The comparative value of table 2 shows that so far as the number of taste buds on a papilla of Japanese is concerned, the maximum is reached at youth period, the maturity period comes next, and the old age the last. On the other hand, the buds on the wall increase slighty from youth to maturity period, but a sudden decrease takes place in old age, and the number is reduced to almost half of that in adult period. The mean total number of taste buds on papilla and wall combined is greatest in youth period and the maturity period very closely comes next and the old age period shows a marked decline.

If above results are compared with what Heiderich described with his materials from birth-20 years of age of Europeans, the average of taste buds on papilla is 248 and those on the wall of its trench is 30 , making the total 
of 270 . This total is greater than that of the Japanese but the number on the wall is less.

Arey and his associates have found the average of 206 taste buds on a papilla and 49 on the wall of its trench in Furopeans between 20-70 years old ; this gives the mean total of 254. Thus the number of the buds on the wall of the trench of Europeans is less than that of Japanese but the mean total is greater. They also found the mean total of 111 buds in the individuals of 74-85 years ; 88 buds on the papilla and 13 on the wall of its trench. This number is sinaller than one which was found in Japanese both in mean total and in each unit. But such diversity may have come from the difference in the age linit. We placed the individuals over 61 years in senile period whereas they raised their limit to above 75 years old. In spite of the difference in the age limit of the senile period, the mean total of the number of taste buds is the highest in infant period, the maturity period comes next and in old age period it shows a marked reduction in both races. Our findings correspond to what Heiderich and Arey discovered. "The inean number of taste buds on the papillae between birth and 20 years is remarkably constant. During maturity and pre-senile period the mean is slightly sinaller. In extreme old age the mean declines....".

If the distribution frequency of the taste buds according to ages is observed, there will be a certain limited number of buds which would be found more frequently than other numbers. This number will be the modal number of that age. Tables 3,4 and 5 show the comparative studies of the distribution frequency of taste buds between Japanese and Europeans.

The table 3 shows that among Japanese from birth to 20 years old the nodal number of taste buds to a papilla is $251-300$, to a trench wall is 0 , and to both papilla and wall combined is 251-300. This value corresponds to the results of Heiderich so far as the papilla and wall of its trench are concerned but for both papilla and wall combined Heiderich's shows at 251-350.

The table 4 shows that in Japanese between 21-60 years old the modal number of taste buds to a papilla is 201-250 and to a trench wall is 1-50; and to both papilla and wall combined is 201-250. Arey and his associates on the other hand show for Europeans from 30-70 years the following. The taste buds to a papilla has two modes: the one is 50-100 and the other is 201-250. The mode for the wall is 1-50, while both for papilla and wall is found between 101-250. 
Table 3. The distribution frequency of taste buds on papillae. The age from birth to 20 years. Findings on 80 papillae of Japanese are compared with those of 96 papillae of Europeans.

\begin{tabular}{|c|c|c|c|c|c|c|}
\hline \multirow{2}{*}{$\begin{array}{l}\text { Naterial } \\
\text { Investi- } \\
\text { gator }\end{array}$} & \multicolumn{3}{|c|}{ Japanese } & \multicolumn{3}{|c|}{ Europeans } \\
\hline & \multicolumn{3}{|c|}{ Mochizuki } & \multicolumn{3}{|c|}{ Heiderich } \\
\hline $\begin{array}{l}\text { Number } \\
\text { of taste } \\
\text { buds }\end{array}$ & $\begin{array}{c}\text { Number of } \\
\text { papillae } \\
\text { bearing this } \\
\text { number of } \\
\text { buds }\end{array}$ & $\begin{array}{l}\text { Number of } \\
\text { walls } \\
\text { bearing this } \\
\text { number of } \\
\text { buds }\end{array}$ & $\begin{array}{l}\text { Number of } \\
\text { papillae and } \\
\text { walls com- } \\
\text { bined bear- } \\
\text { ing this num- } \\
\text { ber of buds }\end{array}$ & $\begin{array}{c}\text { Number of } \\
\text { papillae } \\
\text { bearing this } \\
\text { number of } \\
\text { buds }\end{array}$ & $\begin{array}{c}\text { Number of } \\
\text { walls } \\
\text { bearing this } \\
\text { number of } \\
\text { buds }\end{array}$ & $\begin{array}{l}\text { Number of } \\
\text { papillae and } \\
\text { walls com- } \\
\text { bined bear- } \\
\text { ing this num- } \\
\text { ber of buds }\end{array}$ \\
\hline 0 & 0 & 36 & 0 & 0 & 46 & 0 \\
\hline $1-50$ & 2 & 26 & 2 & 4 & 30 & 3 \\
\hline $51-100$ & 8 & 16 & 5 & 4 & 13 & 4 \\
\hline $101-150$ & 3 & 2 & 4 & 4 & 5 & 3 \\
\hline $151-200$ & 9 & 0 & 6 & 13 & 2 & 11 \\
\hline $201-250$ & 13 & 0 & 12 & 15 & 0 & 13 \\
\hline $251-300$ & 27 & 0 & 21 & 35 & 0 & 23 \\
\hline $301-350$ & 12 & 0 & 16 & 14 & 0 & 22 \\
\hline $351-400$ & 1 & 0 & 6 & 3 & 0 & 8 \\
\hline $401-450$ & 5 & 0 & 3 & 3 & 0 & 4 \\
\hline $451-500$ & 0 & 0 & 5 & 0 & 0 & 3 \\
\hline $501-550$ & 0 & 0 & 0 & 1 & 0 & 2 \\
\hline
\end{tabular}

Table 4. The distribution frequency of taste buds in 69 Japanese circumvallate papillae and their walls. Age range from 21-60 years.

This is compared with 102 European papillae of $30-70$ years.

\begin{tabular}{|c|c|c|c|c|c|c|}
\hline \multirow{2}{*}{$\begin{array}{l}\text { Material } \\
\text { Investi- } \\
\text { gator }\end{array}$} & \multicolumn{3}{|c|}{ Japanese } & \multicolumn{3}{|c|}{ Europeans } \\
\hline & \multicolumn{3}{|c|}{ Mochizuki } & \multicolumn{3}{|c|}{ Ares, Tremaine and MIonzingo. } \\
\hline $\begin{array}{l}\text { Number } \\
\text { of taste } \\
\text { buds }\end{array}$ & $\begin{array}{c}\text { Number of } \\
\text { papillae } \\
\text { bearing this } \\
\text { number of } \\
\text { buds }\end{array}$ & $\begin{array}{c}\text { Number of } \\
\text { walls } \\
\text { bearing this } \\
\text { number of } \\
\text { buds }\end{array}$ & $\begin{array}{l}\text { Number of } \\
\text { papillae and } \\
\text { walls com- } \\
\text { bined beal- } \\
\text { ing this num- } \\
\text { ber of buds }\end{array}$ & $\begin{array}{c}\text { Number of } \\
\text { papillae } \\
\text { hearing this } \\
\text { number of } \\
\text { buds }\end{array}$ & $\begin{array}{c}\text { Number of } \\
\text { walls } \\
\text { bearing this } \\
\text { number of } \\
\text { buds }\end{array}$ & $\begin{array}{l}\text { Number of } \\
\text { papillae and } \\
\text { walls com- } \\
\text { bined bear- } \\
\text { ing this num- } \\
\text { her of buds }\end{array}$ \\
\hline 0 & 0 & 24 & 0 & 0 & 23 & 0 \\
\hline $1-50$ & 4 & 28 & 4 & 5 & 41 & 4 \\
\hline $51-100$ & 5 & 9 & 5 & 20 & 19 & 11 \\
\hline $101-150$ & 13 & 7 & 5 & 15 & 10 & 14 \\
\hline $151-200$ & 14 & 1 & 12 & 10 & 6 & 13 \\
\hline $201-250$ & 17 & 0 & 19 & 18 & 1 & 14 \\
\hline $251-300$ & 6 & 0 & 7 & 15 & 0 & 12 \\
\hline $301-350$ & 7 & 0 & 10 & 7 & 0 & 11 \\
\hline $351-400$ & 1 & 0 & 2 & 6 & 0 & 8 \\
\hline $401-450$ & 0 & 0 & $: 3$ & 1 & 0 & 5 \\
\hline $451-500$ & 1 & 0 & 0 & 2 & 0 & 3 \\
\hline $501-550$ & 0 & 0 & 1 & 2 & 0 & 4 \\
\hline $551-600$ & 1 & 0 & 0 & 0 & 0 & 1 \\
\hline $601-6 i 0$ & 0 & 0 & 1 & 0 & 0 & 0 \\
\hline $651-700$ & 0 & 0 & 0 & 0 & 0 & 1 \\
\hline $701-750$ & 0 & 0 & 0 & 0 & 0 & 0 \\
\hline $751-800$ & 0 & 0 & 0 & 1 & 0 & 0 \\
\hline $801-850$ & 0 & 0 & 0 & 0 & 0 & 0 \\
\hline $851--900$ & 0 & 0 & 0 & 0 & 0 & 1 \\
\hline
\end{tabular}


The nodal number on papilla in Japanese therefore corresponds to one of two modes of Europeans, that is from 201-250. And as to both papilla and wall combined, it corresponds to the greatest of 2 series of Europeans, namely 201-250. The modal number on the wall of trench is the same for both. In maturity period and in early senile period, both in Japanese and Europeans, the number of buds found on papillae is about the same. But if papillae and walls are combined, Japanese has greater nuinber than the Europeans.

Table 5. The distribution frequency of taste buds in 104 Japanese circumvallate papillae and their walls. Age range from

61-90 years. This is compared with 46 Europeans between $74-85$ years.

\begin{tabular}{|c|c|c|c|c|c|c|}
\hline Material & \multicolumn{3}{|c|}{ Japanese } & \multicolumn{3}{|c|}{ Europeans } \\
\hline $\begin{array}{l}\text { Investi- } \\
\text { gator }\end{array}$ & \multicolumn{3}{|c|}{ Mochizuki } & \multicolumn{3}{|c|}{ Arey, Tremaine and MIonzingo } \\
\hline $\begin{array}{l}\text { Number } \\
\text { of taste } \\
\text { buds }\end{array}$ & $\begin{array}{c}\text { Number of } \\
\text { papillae } \\
\text { bearing this } \\
\text { number of } \\
\text { buds }\end{array}$ & $\begin{array}{l}\text { Number of } \\
\text { walls } \\
\text { bearing this } \\
\text { number of } \\
\text { buds }\end{array}$ & $\begin{array}{l}\text { Number of } \\
\text { papillae and } \\
\text { walls com- } \\
\text { bined bear- } \\
\text { ing this num- } \\
\text { ber of buds }\end{array}$ & $\begin{array}{c}\text { Number of } \\
\text { papillae } \\
\text { bearing this } \\
\text { number of } \\
\text { buds }\end{array}$ & $\begin{array}{c}\text { Number of } \\
\text { walls } \\
\text { bearing this } \\
\text { number of } \\
\text { buds }\end{array}$ & $\begin{array}{l}\text { Number of } \\
\text { papillae and } \\
\text { walls com- } \\
\text { bined bear- } \\
\text { ing this num- } \\
\text { ber of buds }\end{array}$ \\
\hline 0 & 0 & 21 & 0 & 3 & 25 & 3 \\
\hline $1-50$ & 11 & 74 & 4 & 21 & 18 & 19 \\
\hline $51-100$ & 25 & 9 & 24 & 9 & 2 & 8 \\
\hline $101-150$ & 41 & 0 & 38 & 5 & 1 & 7 \\
\hline $151-200$ & 22 & 0 & 17 & 2 & 0 & 2 \\
\hline $201-250$ & 3 & 0 & 13 & 1 & 0 & 1 \\
\hline $251-300$ & 1 & 0 & 7 & 2 & 0 & 2 \\
\hline $301-350$ & 0 & 0 & 0 & 2 & 0 & 1 \\
\hline $351-400$ & 0 & 0 & 0 & 1 & 0 & 2 \\
\hline $401-450$ & 0 & 0 & 0 & 0 & 0 & 1 \\
\hline $451-500$ & 1 & 0 & 1 & 0 & 0 & 0 \\
\hline
\end{tabular}

The modal number of the taste buds to a papilla in senile Japanese is concentrated between 101-150, whereas the wall has 1-50. The total number is 51-150. For the Europeans between 74-85 years old show 1-50, 0, and 1-50 respectively. The unit for unit, the Europeans have lower value than the Japanese.

If the results which are tabulated in tables 3,4 and 5 are reviewed, we can see that in Japanese the number of taste buds per papilla in the circumvallate papillae is 251-300 in infant period, 201-250 in maturity, and 101-150 in old age. Thus the number runs inversely to the 
advancement of age. As for the number of buds on the walls, there are cases in which they are lacking in infant period, and 1-50 is the modal number in maturity, and which are again lacking in many cases, in old age period. The combined number of the buds in papillae and walls in infant period is 251-300, and in maturity 201-250, and in old age period 101-150. Thus the modal number decreases as the age advances.

The comparison between Japanese and Europeans shows that both races have about the same tendency in the variability of the modal number of taste buds in each unit. That is the nodal number of taste buds decreases as the age advances, and they are lacking on trench walls in infant period and there are few in maturity period. The number again decreases in old age.

Detailed examinations of these two races with reference to ages and the nodal number of taste buds per papilla, however, show that they are about the same in maturity period but the Europeans have more in the young age group than the Japanese, whereas the Japanese have more than the Europeans in old age group. As for the nodal number of taste buds on the walls are concerned these two races have practically similar tendency, but the degree of variation in Japanese is somewhat more gradual than that of Europeans.

Table 6. The number of taste buds per papilla according to age group, from birth to 90 years.

\begin{tabular}{c|c|c|c|c|c}
\hline \hline Age & $\begin{array}{c}\text { Number of } \\
\text { individual } \\
\text { used }\end{array}$ & $\begin{array}{c}\text { Number of } \\
\text { papillae } \\
\text { studied }\end{array}$ & $\begin{array}{c}\text { Papilla } \\
\text { with less } \\
\text { than 200 } \\
\text { taste buds }\end{array}$ & $\begin{array}{c}\text { Papilla } \\
\text { with } \\
\text { between } \\
201-300 \text { taste } \\
\text { buds }\end{array}$ & $\begin{array}{c}\text { Papilla } \\
\text { with more } \\
\text { than 300 } \\
\text { taste buds }\end{array}$ \\
\hline Birth-10 years & 23 & 50 & $\begin{array}{c}\text { (per cent) } \\
24.0\end{array}$ & $\begin{array}{c}\text { (per cent) } \\
48.0\end{array}$ & $\begin{array}{c}\text { (per cent) } \\
28.0\end{array}$ \\
11 years-20 years & 12 & 30 & 30.0 & 53.3 & 16.7 \\
21 years-30 years & 11 & 20 & 45.0 & 45.0 & 10.0 \\
31 years-40 years & 11 & 22 & 45.5 & 36.3 & 18.2 \\
41 years-50 years & 13 & 20 & 55.0 & 30.0 & 15.0 \\
51 years-60 years & 6 & 7 & 85.7 & 14.3 & 0 \\
61 years-70 years & 20 & 40 & 92.5 & 5.0 & 2.5 \\
71 years-80 years & 20 & 40 & 95.0 & 5.0 & 0 \\
81 years-90 years & 12 & 24 & 100.0 & 0 & 0
\end{tabular}

Table 6 attempts to show the variation of distribution frequency of papillae in different age group by taking the papillae which have the taste buds between 201-300 per papilla as base line. The distribution frequency is given in percent. The number of papillae which have 201-300 taste 
buds are found more in birth and infant period, and begins to decrease between adult period to old age period. The number of papillae which have the taste buds less than 200 gradually increase from birth to old age period. These evidences show two facts; that the papillae at birth have already been provided with many taste buds, and that the number of taste buds decreases as the age advances. Similarly, the number of papillae which have more than 301 are also found in high percentage, and it gradually decreases with advancement of age.

Table 7. The number of taste buds on trench walls with reference to age group, from Brith to 90 years.

\begin{tabular}{|c|c|c|c|c|c|}
\hline Age & $\begin{array}{c}\text { Number of } \\
\text { individuals } \\
\text { used }\end{array}$ & $\begin{array}{l}\text { Number of } \\
\text { walls } \\
\text { studied }\end{array}$ & $\begin{array}{c}\text { Walls } \\
\text { without } \\
\text { taste bud }\end{array}$ & $\begin{array}{c}\text { Walls } \\
\text { with 1-50 } \\
\text { taste buds }\end{array}$ & $\begin{array}{l}\text { Walls with } \\
\text { over } 51 \\
\text { taste buds }\end{array}$ \\
\hline Birth-10 years & 23 & 50 & $\begin{array}{c}\text { (per cent) } \\
45.0\end{array}$ & $\begin{array}{c}\text { (per cent) } \\
28.0\end{array}$ & $\begin{array}{c}\text { (per cent) } \\
27.0\end{array}$ \\
\hline 11 years-20 years & 12 & 30 & 43.0 & 30.0 & 27.0 \\
\hline 21 years -30 years & 11 & 20 & 45.0 & 30.0 & 25.0 \\
\hline 31 years -40 years & 11 & 22 & 27.3 & 50.0 & 22.7 \\
\hline 41 years -50 years & 13 & 20 & 40.0 & 40.0 & 20.0 \\
\hline 51 jears-60 years & 6 & 7 & 14.2 & 42.9 & 42.9 \\
\hline 61 years --70 years & 20 & 40 & 17.5 & 72.5 & 10.0 \\
\hline 71 years-80 sears & 20 & 40 & 20.5 & 60.0 & 19.5 \\
\hline 81 years -90 years & 12 & 24 & 16.7 & 79.2 & 4.1 \\
\hline
\end{tabular}

Table 7 shows that there are more taste buds on walls in maturity period than in youth and senile periods. The fact that many taste buds on papilla are already provided at birth and they decrease inversely as the years increase, as we have already seen, is an interesting contrast with the taste buds in walls which are less at the time of birth but reaches to maximum in maturity period, and becomes less again in senile period. The changes of number of taste buds on papilla and wall therefore have separate and distinct tendency. It is, however, of some interest to observe the fact that comparatively slow increase of the number of taste bubs on walls from birth to maturity period decreases rapidly in senile period.

The vertical distribution of taste buds on the side of papillae was studied, and we discovered that the buds are few in number near the top and more in the deeper level, and again becomes less at the bottom of the trench. From the lower third up to the middle part of papilla is the region where maximum number of taste buds are located. Hoffmann (1875) 
reports that the buds are found on the top surface of fetus and infant papilla. $\mathrm{He}$, also, described rare cases where the buds were found in the adult papilla. But the author was not able to come across any such case in his material except in very rare instances where some buds were found near the top of papilla in shallow trench. The presence of taste buds in such region seems to indicate for the compensation of the distribution on the wall on account of the shallowness of the trench.

The distribution of taste buds on papillae is very irregular and the mode of arrangement also is not at all uniform. A great number of papillae for example may have many taste buds on one side and a few or none on the other side. In some rare cases the taste buds were found on all sides of the papilla. Even in such cases, the distribution of buds is by no means regular. We saw a few papillae in which a sinall number of taste buds were grouped together in a sinall patches in certain limited areas on the side.

The same could be said of taste buds on the walls of the trench; that is, the distribution and arrangement of them is uneven. We even saw a total absence of taste buds ainong very young and senile periods. Furthermore, there were some indications of atrophy of taste buds by leaving indistinct outline of the buds, or showing the total absence of such an outline, or the contours become indefinite. The cases of indistinct contours of taste buds were found more so in the papillae in which only a few buds were remaining.

A large size papilla does not necessarily have a great number of taste buds. A selection of a large and fine looking papilla by naked eye often proved to be contrary to expectation, and has been found to possess only a few taste buds, whereas the papilla of nominal size and ordinary looking gave a good quantity of buds. Frequently, our materials showed that the trench, on one side was deeper than the other side, or a trench, on one side is deep and on the other side it gradually became shallower leaving a mere trace of it or else it finally disappeared. More taste buds were found on the deeper trench than in the shallow trench.

\section{Conclusion}

The studies of circumvallate papillae of 128 Japanese from birth to 90 years with reference to the number of taste buds and their topographical relations were compared to those of Heiderich (from birth to 20 years) and those of Arey and his associates (20-85 years). 
1. The nean number of taste buds on the papilla in the period of birth to twenty years is 242 , and this number is reduced to 196 in maturity and in early senile period (21-60 years), further reduction takes place in old age period, over 61 years old, becoming 116. This reduction in the old age period is due to atrophy and consequent disappearance of taste buds.

2. The nnean number of taste buds on the walls of trench in early period (birth to 20 years) is 48 , and it increases slightly in maturity period by giving the count of 52 . In old age period, the number becomes suddenly low, as is the case in papilla, and is being reduced to 28 , alınost half of the value of that in maturity period.

3. The mean number of taste buds combined those of on papilla and on wall in birth-20 years is 269 , and in maturity period 234 . A slight decrease in total number in maturity period is due to the reduction of taste buds on papilla, but the number of buds on the walls of trench increases in this period to compensate to some extent the loss on papilla. In old age period, however, a sudden reduction takes place and the total becomes 140 .

4. The modal number of taste buds for papilla between birth and 20 years old is from 251-300 and none for the wall. The same for the pericd between 21-60 years is 201-250 for the papilla and 1-50 for the wall. In old age period (61-90 years) the number for the papilla becomes 101-150, and 1-50 for the wall. Thus the nodal number of taste buds for papilla decreases as the age advances, whereas that for the wall increases from infant to youth.

5. As far as the statistical evidences from our investigation is concerned, the taste buds are already present abundantly on the papillae at the time of birth, but those in the wall increase after birth. These buds begin to disappear from these two regions in maturity period, and this process is rapidly accelerated in old age period.

6. The mean number of taste buds on papilla of Japanese is somewhat sinaller than that of Europeans. The decrease of the number of buds in the old age period anong Japanese is not as great and rapid as that of ainong Furopeans.

7. The maximum number of taste buds per papilla was 559, and 173 for the wall. The highest number was 624 in combination of papilla and wall.

8. The minimum number of taste buds per papilla was 12 , and none per the wall. The latter case was observed frequently through all ages. The lowest combined number, per papilla and wall, was 12 . There never was a case of absolute absence of taste buds on papilla among the Japanese, though there are such among the Europeans. 
9. No taste bud is found on the top surface of a papilla, though occasionally a few or more buds are found on the side or near the top. surface. Such cases are usually found in the papillae which have shallow trench. The region where the naximum number of taste buds are found on the wall is at the middle section of the wall and about $1 / 3$ downward.

10. The distribution of taste buds on a papilla and its trench wall is not uniform. Their position is arbitrary, and arrangement is irregular. Some papilla shows a tendency to group on one side.

11. In a given circumvallate papillae, a great number of taste buds is generally found on papilla and a low number is on the trench wall. There is no correlation between the size of papilla and the number of taste buds. In other words a large size papilla does not necessarily posess a great number of taste buds.

12. The size of papilla invariably differ from one another. A trench on one side of papilla sometimes may be deep and the one on the other side may be shallow. In such case, more taste buds are found on the wall of papilla which faces the deeper trench than the wall facing the shallow trench.

\section{Literatur}

1. Malpighius, MI.: 1664, Epistola de lingua (cited from Anat. Rec., Vol. 64, p. 9, 1936.)

2. Lovén, O. C.: 1867, Bidrag till kännendomen om tungans smakpapiller. (cited from Anat, Rec. Vol. 64, p. 9, 1936.)

3. Schwalbe, G.: 1867, Das Epithel der Papillae vallatae. Arch. f. mikr. Anat., Bd. 3, S. $504-508$.

4. Lovén, C.: 1869, Beiträge zur Kenntnis vom Bau der Geschmackswärzchen der Zunge. (cited from Anat. Rec. Vol. 64, p. 9, 1936.)

5. Schwalbe, G.: 1868, Über die Geschmacksorgane der Säugetiere und des Menschen. Arch. f. mikr. Anat., Bd. 4, S. 154-187.

6. v. Wyss, H.: 1870, Die becherförmigen Organe der Zunge. Arch. f. mikr. Anat., Bd. 6, S. 237-260.

7. Krause, W.: 1870, Die Nerven-Endigung in der Zunge des Menschen. Nachr. v. d. kön. Gesell. d. Wiss. z. Göttingen. Jahrg., No. 21, \$. 423-426.

8. Hoffmann, A.: 1875, Über die Verbreitung der Geschmacksknospen beim Menschen. Arch. f. path. Anat. u. Physiol., Bd. 62, S. 516-530.

9. Krause, W.: 1876, Handbuch der menschlichen Anatomie. Bd. 1, allgemeine und mikroskopische Anatomie. Hahn, Hannover, S. 14-581, 1876.

10. Gråberg, J.: 1899, Zur Kenntnis des zellulären Baues der Geschmacksknospen beim Menschen. Anat., Hefte, Bd. 12, S. 337-368. 
11. Heiderich, F.: 1906, Die Zahl und die Dimension der Geschmacksknospen der Papilla vallata des Menschen in den verschiedenen Lebensaltern. Nachr v. d. kön. Gesell. d. Wiss. z. Göttingen. Math.-Physik. Kl., Heft. I. S. 54-64.

12. Arey, L., Tremaine, M. and Monzingo, F.: 1936, The numerical and topographical relations of taste buds to human circumvallate papillae throughout the life span. Anat. Rec., Vol. 64, pp. 9-25. 